\title{
Wildlife, Water Quality, and the Public Trust Doctrine: A Means of Enforcing Agricultural Nonpoint Source Pollution Management Plans
}

Veronique Jarrell-King

Follow this and additional works at: https://digitalcommons.law.villanova.edu/elj

Part of the Environmental Law Commons, and the Land Use Law Commons

\section{Recommended Citation}

Veronique Jarrell-King, Wildlife, Water Quality, and the Public Trust Doctrine: A Means of Enforcing Agricultural Nonpoint Source Pollution Management Plans, 23 Vill. Envtl. L.J. 1 (2012).

Available at: https://digitalcommons.law.villanova.edu/elj/vol23/iss1/1 


\title{
VILLANOVA ENVIRONMENTAL LAW JOURNAL
}

WILDLIFE, WATER QUALITY, AND THE PUBLIC TRUST

DOCTRINE: A MEANS OF ENFORCING AGRICULTURAL NONPOINT SOURCE POLLUTION MANAGEMENT PLANS

\author{
VéroniQue Jarrell-King*
}

\section{INTRODUCTION}

Throughout the nation, entire amphibian populations are experiencing reproductive and developmental defects that threaten their survival. ${ }^{1}$ This damage is attributable to the runoff of herbicides, such as atrazine, from agricultural fields, which have managed to successfully evade regulation under the Clean Water Act (CWA). ${ }^{2}$ Agricultural nonpoint source pollution in the nation's waterways not only affects amphibians, but also other wildlife species residing in the waters. ${ }^{3}$ This, in turn, impacts humans and other

* Véronique Jarrell-King is a J.D. and Master of Environmental Law and Policy Candidate, 2012, at Vermont Law School. She received her B.A. in 2006 from the University of Colorado.

1. Tyrone B. Hayes et al., Hermaphroditic, Demasculinized Frogs After Exposure to the Herbicide Atrazine at Low Ecologically Relevant Doses, 99 Proc. OF THE NAT'L Acad. OF SCIS. OF THE U.S. 5476, 5479 (2002) (discussing how current levels of atrazine application to agricultural areas could impair reproductive function in amphibians and lead to population decline and extinction).

2. F. Orton et al., Effects of Nitrate and Atrazine on Larval Development and Sexual Differentiation in the Northern Leopard Frog Rana Pipiens, 25 ENVTL. TOxICology \& Chemistry 65, 65 (2006) (discussing possible link between amphibian population decline and agricultural pollutants, such as atrazine); see also Clean Water Act, 33 U.S.C. $\$ 1251$ (1994) (providing goals and policy of Clean Water Act).

3. See, e.g., B. Lal, Pesticide-Induced Reproductive Dysfunction in Indian Fishes, 33 Fish Physiology \& Biochemistry 455, 455 (2007) (noting studies have shown pesticides to effect or damage gonadal development, fertilization, fecundity, and lower hormonal levels in Indian fishes); Santi Mañosa et al., A Review of the Effects of Agricultural and Industrial Contamination on the Ebro Delta Biota and Wildlife, 71 Envtl. Monitoring \& Assessment 187, 191 (2001) (finding massive use of herbicides has caused loss in biodiversity, greatly damaging diving ducks and coot populations); Jeremy David Rouse et al., Nitrogen Pollution: An Assessment of its Threat to Amphibian Survival, 107 Envtr. Health Persp. 799, 799 (1999) (finding nitrogen concentrations near Great Lakes sufficient to cause death and developmental ab- 
Vili.anova EnVIronmental LaW Journal [Vol. XXIII: p. 1

species reliant upon the affected wildlife as a source of food. ${ }^{4}$ Thus, in response to the CWA's failure to adequately regulate agricultural nonpoint source pollution, citizens should look to the public trust doctrine as a means of requiring state agencies to more effectively address nonpoint source pollution and reduce its detrimental effects on wildlife.

The public trust doctrine provides members of the public with a means of ensuring the government protects the public's interest in common resources-resources held in a trust by the government for the people. ${ }^{5}$ One of the greatest strengths of the public trust doctrine is it "can sometimes give greater recognition to public interests at times when legislatures are under excessive pressure by special interest lobbyists." ${ }^{\circ}$ Because agricultural interest groups have developed into such a powerful force, they have the potential to sway state agencies and effectively avoid the voluntary nonpoint source pollution regulations set forth in the CWA. ${ }^{7}$ As a result, many legislatures and agencies face excessive pressure when attempting to implement agricultural nonpoint source pollution control plans under $\S 319$ of the CWA. ${ }^{8}$ Through the public trust doctrine, however, citizens have the potential to challenge an agency's failure to consider the public's interest in wildlife when the agency develops and reviews nonpoint source pollution control plans, even in the face of strong political pressure from agricultural lobbyists. ${ }^{9}$

This article examines the potential use of the public trust doctrine by members of the public to require state and local agencies to consider the public's interest in wildlife protection and water quality dependent public trust uses when the agency determines

normalities in amphibians in addition to adversely affecting other animals in aquatic ecosystems).

4. See Lal, supra note 3, at 455 (discussing impacts on Indian Fishes); Mañosa, supra note 3,187 (discussing impacts on diving ducks and coot populations); Rouse, supra note 3, at 799 (discussing impacts on amphibians).

5. Anna R.C. Caspersen, The Public Trust Doctrine and the Impossibility of "Takings" by Wildlife, 23 B.C. ENVTL. Afr. L. Rev. 357, 358 (1996) (indicating public trust doctrine stresses duty to protect and preserve natural resources).

6. Ralph W. Johnson, Water Pollution and the Public Trust Doctrine, 19 ENVTL. L. 485, 511 (1989) (explaining advantages and disadvantages of public trust doctrine).

7. See David Zaring, Agriculture, Nonpoint Source Pollution, and Regulatory Control: The Clean Water Act's Bleak Present and Future, 20 Harv. Envtl. L. Rev. 515, 542-43 (1996) (suggesting outside influences affecting implementation of CWA).

8. Johnson, supra note 6, at 511 (describing pressures asserted on legislative process).

9. For further discussion, see infra Part V and notes 144-157. 
whether to implement the $\$ 319$ nonpoint source regulation. ${ }^{10}$ Specifically, the article explores whether the public can use the public trust doctrine as a means to require state agencies to better regulate agricultural nonpoint source pollution that damages the public's interest in protecting its wildlife. ${ }^{11}$ The public trust doctrine varies in each state depending on the extent its common law evolved to address water quality and wildlife protection; therefore, California has the greatest potential to use the public trust doctrine to urge the enforcement of nonpoint source pollution regulation. ${ }^{12}$ There is no reason, however, the public trust doctrine could not be utilized in other states in the future if the common law foundations allow for it. ${ }^{13}$

Part II of this article provides background on the public trust doctrine, and focuses on the public's interest in wildlife and public trust uses that depend on water quality protection. ${ }^{14}$ Part III addresses the detrimental effects of agricultural pollution on wildlife and water quality; specifically, the potential fatal effects of the herbicide atrazine on amphibian development and reproduction. ${ }^{15}$ In Part IV, this article provides the background and shortcomings of $\S \S 208$ and 319 of the CWA and explains how those sections have led to ineffective regulatory controls over nonpoint source pollution in the United States. ${ }^{16}$ Lastly, Part V discusses the potential to use the public trust doctrine as a means of ensuring state and local government agencies fulfill their duties in considering the public's interests when developing and implementing $\$ 319$ nonpoint source pollution control plans. ${ }^{17}$

10. For further discussion, see infra Part V and notes 144-157.

11. For further discussion, see infra Part V and notes 144-157.

12. See Nat'l Audubon Soc'y v. Superior Court of Alpine Cnty., 658 P.2d 709, 719 (Cal. 1983) (describing evolution of public trust in California in tandem with public values); Ctr. for Biological Diversity, Inc. v. FPL Grp., Inc., 83 Cal. Rptr. 3d 588, 595-96 (Cal. Ct. App. 2008) (describing scope of public trust in California).

13. See infra note 156 for an overview of states with common law foundations for wildlife and water quality protection.

14. For further exploration of the origin of the public trust doctrine, see infra Part II and notes $18-80$.

15. For further discussion of the damage pollutants caused to the environment, see infra Part III and notes 81-107.

16. For further discourse of how some sections of the CWA have not achieved their desired effects, see infra Part IV and notes 108-143.

17. For further examination of the public trust doctrine's potential, see infra Part V and notes 144-157. 


\section{Public Trust Doctrine}

[T] he public trust is more than an affirmation of state power to use public property for public purposes. It is an affirmation of the duty of the state to protect the people's common heritage of streams, lakes, marshlands and tidelands, surrendering that right of protection only in rare cases when the abandonment of that right is consistent with the purposes of the trust. ${ }^{18}$

The public trust doctrine creates a legal duty in the states to hold natural resources in a trust for the benefit of the public, and protect and preserve the resources for future generations. ${ }^{19}$ The strength of the doctrine stems from the fact that private citizens can sue a government agency and demand the agency recognize the public's interests as a whole when making decisions that impact those interests. ${ }^{20}$ The doctrine has been recognized as encompassing a diverse breadth of interests, such as the submerged lands of navigable waterways, the value of entire ecological systems, and the water quality impacting public trust uses. ${ }^{21}$

The concept of the public trust arose under Roman law, where natural resources, "such as air, water, and wildlife," were viewed as commonly owned by the public, as they were items no individual could own in their entirety. ${ }^{22}$ The public trust notion was subse-

18. Nat'l Audubon Soc'y v. Superior Court of Alpine Cnty., 658 P.2d 709, 724 (Cal. 1983) (describing duties of state as trustee of public trust).

19. Caspersen, supra note 5 , at 358 (discussing public trust doctrine's influence on society at large).

20. See Deborah G. Musiker et al., The Public Trust and Parens Patriae Doctrines: Protecting Wildlife in Uncertain Political Times, 16 Pub. LAND L. Rev. 87, 95 (1995) (noting citizens may seek relief in court when agencies fail to consider public trust interests). California is a prime example of a state that allows citizens to bring an independent action against an agency under the public trust doctrine when an agency fails to recognize the public trust when performing their duties. See Ctr. for Biological Diversity, Inc. v. FPL Grp., Inc., 83 Cal. Rptr. 3d 588, 601 (Cal. Ct. App. 2008). In other states, however, public trust enforcement claims are raised as part of another proceeding, not as their own cause of action. See In re Steuart Transp. Co., 495 F. Supp. 38, 39-40 (E.D. Va. 1980) (bringing case for damages and cleanup costs and subsequently raising public trust doctrine claim).

21. Ill. Cent. R.R. v. Illinois, 146 U.S. 387, 455 (1892) (noting navigable waters and soil below are held in public trust); Nat'l Audubon Soc'y, 658 P.2d at 719 (recognizing importance of water quality in protecting public interest in scenic and ecological value of Mono Lake).

22. Caspersen, supra note 5, at 363 (illustrating Roman law's influence on idea of common ownership under public trust doctrine); see also Greer v. Connecticut, 161 U.S. 519, 522 (1896), overruled by Hughes v. Oklahoma, 441 U.S. 322 (1979) (discussing commonly owned property could include animals and ferae naturae which were believed to belong to all citizens of state). 
quently recognized under the common law of England, whereby the king retained ownership of the lands and granted access to the public for the purpose of grazing, hunting, foraging, and fishing. ${ }^{23}$ In essence, the king held and protected the resources for the public to use. ${ }^{24}$

The public trust doctrine resurfaced in the United States when Americans began to realize the nation's resources were finite and public access to such resources needed to be preserved. ${ }^{25}$ In the seminal case on the public trust doctrine, Illinois Central Railroad Co. v. Illinois (Illinois Central), ${ }^{26}$ the Supreme Court of the United States determined Illinois held the shore of Lake Michigan in public trust, and thus could transfer the shore land to a private owner only if Illinois retained discretion and control over the land. ${ }^{27}$ By virtue of its sovereignty, the Court deemed the State to hold both the navigable waters and the soils below in a trust for the people of the State. ${ }^{28}$

Following Illinois Central, courts have extended the public trust doctrine to other uses such as boating, rafting, and hunting, and to other resources such as wildlife habit, water, groundwater, wetlands, and areas of dry sand. ${ }^{29}$ Most importantly, the public trust doctrine continues to evolve; it constantly expands and reshapes based on the values and needs of the citizens of each state. ${ }^{30}$

23. Caspersen, supra note 5, at 364-65 (documenting origins of public trust doctrine).

24. Id. (describing how states inherited notion of public trust from king).

25. Id. at 365-66 (discussing eventual progression of public trust doctrine from public access focus to role of preservation).

26. 146 U.S. 387 (1892).

27. Ill. Cent. R.R, 146 U.S. at 453 (noting only time state could relinquish duty to exercise management and control over public trust property was when doing so was in public's best interest or when disposing of property did not impair public's remaining trust interests).

28. Id. at 455 (explaining common public interest in maintaining ownership of navigable waters).

29. Matthews v. Bay Head Improvement Ass'n, 471 A.2d 355, 365-66 (N.J. 1984) (recognizing public interest in dry sand areas); Ctr. for Biological Diversity, Inc. v. FPL Grp., Inc., 83 Cal. Rptr. 3d 588, 595-600 (Cal. Ct. App. 2008) (recognizing interests in tidelands, navigable waters, and more); see also Musiker, supra note 20 , at 92 (noting courts' broad interpretation of public trust doctrine).

30. Mary Christina Wood, Advancing the Sovereign Trust of Government to Safeguard the Environment for Present and Future Generations (Part I): Ecological Realism and the Need for a Paradigm Shift, 39 ENVTL. L. 43, 80 (2009) (questioning elasticity of public trust doctrine to effectuate needs of ever-changing society). 


\section{A. Enforcement of the Public Trust Doctrine}

"The heart of the public trust doctrine, however it may be articulated, is that it imposes limits and obligations on governments." ${ }_{11}$ Each branch of the government is allocated specific duties in order to ensure the public's interests are recognized and protected. ${ }^{32}$ In a sense, the legislature is the trustee of the trust because it enacts the laws of the state that will best protect the public trust, and the executive branch is the agent. ${ }^{33}$ As the agent, the executive branch, through its state and federal agencies, has the duty to enforce the trust obligations set forth by each state legislature. ${ }^{34}$ A state agency has "an affirmative duty to take the public trust into account in the planning and allocat[ing] of ... resources, and to protect public trust uses whenever feasible" to minimize harm. ${ }^{35}$ In addition, once a state agency approves a plan affecting a public trust resource, the agency has a duty to continue supervising the use of the resource and the power to reconsider any past decisions inconsistent or contrary to the needs of the public. ${ }^{36}$

The judicial branch, however, is the "ultimate guardian of the trust," protecting the public's rights in public trust resources. ${ }^{37}$ When using the judicial branch to protect their rights, citizens must overcome two primary hurdles: a valid cause of action and standing. ${ }^{38}$ In California, if an agency fails to perform its duties or consider the public interest in making a decision, the public may bring

31. Charles F. Wilkinson, The Public Trust Doctrine in Public Land Law, 14 U.C. Davis L. REv. 269, 284 (1980-1981) (discussing public trust doctrine in limiting federal power); see also Ill. Cent. R.R., 146 U.S. at 454 (opining state was restricted from turning land held in public trust over to private company because it was required to hold for public); In re Steuart Transp. Co., 495 F. Supp. 38, 40 (E.D. Va. 1980) (finding because no individual citizen could recover for loss of waterfowl, it was "right and the duty" of state to protect and preserve public's interest in wildlife resources for them).

32. Wood, supra note 30, at 75-77 (explaining duties of government branches).

33. Id. at 75 (illustrating role of government branches in public trust); see also Greer v. Connecticut, 161 U.S. 519, 533-34 (1896)), overmiled by Hughes v. Oklahoma, 441 U.S. 322 (1979) (describing role of legislature).

34. Wood, supra note 30 , at 75 (explaining duty of executive branch to enforce legislature).

35. Nat'l Audubon Soc'y v. Superior Court of Alpine Cnty., 658 P.2d 709, 728 (Cal. 1983) (illustrating role of state agency in protecting public interest).

36. Id. (describing supervising power of state agency over public trust resource).

37. Wood, supra note 30 , at 75 (explaining role of judiciary in protecting public rights); Gary D. Meyers, Variation on a Theme: Expanding the Public Trust Doctrine to Include Protection of Wildlife, 19 ENVTL. L. 723, 731 (1989) (describing impact of judicial branch on public trust resources).

38. See discussion infra notes $41-42$ and accompanying text. 
an action to enforce the trust and compel that agency to perform its duties. ${ }^{39}$ Though many states do not offer a public trust enforcement cause of action, the public may raise the claim as part of a proceeding. ${ }^{40}$ Once there is a valid cause of action, some courts, such as those in Hawaii, Illinois, and California, have granted citizens standing to enforce the doctrine in certain instances, while other refuse to do the same. ${ }^{41}$ Once these barriers are surmounted, members of the public benefit when courts perceive agency actions-actions which restrict public uses or place them in the hands of a private party's self interest-with "considerable skepticism." 42 The public trust places a fiduciary obligation on the agency to protect the public trust resources, and when the agency fails to do so, courts will review public trust cases with "meaningful judicial scrutiny." 43

39. Ctr. for Biological Diversity, Inc. v. FPL Grp., Inc., 83 Cal. Rptr. 3d 588, 602-03 (Cal. Ct. App. 2008) (explaining rights of citizens to bring action in California); Musiker, supra note 20 , at 96 (describing process for citizens bringing action in California).

40. In re Steuart Transp. Co., 495 F. Supp. 38, 39-40 (E.D. Va. 1980) (allowing public trust enforcement as part of proceeding); Owsichek v. Alaska Guide Licensing \& Control Bd., 763 P.2d 488, 491 (Alaska 1988) (permitting public trust claim); Kootenai Envtl. Alliance v. Panhandle Yacht Club, Inc., 671 P.2d 1085, 1094-95 (Idaho 1983) (permitting public trust cause of action). In these states, the public trust doctrine is often raised in cases brought before the court for permit compliance and validity, tort damages, and questions on the constitutionality of a statute. See supra.

41. Sierra Club v. Dep't of Transp., 167 P.3d 292, 313 (Haw. 2007) (finding even though member of public must still meet three-part standing test, as environmental plaintiff their injury need not be particularized because harm to plaintiff's environmental interests may be sufficient for standing). This court also noted a less rigorous standing requirement was available for environmental plaintiffs under the Hawai'i Constitution Article XI, §9. Id. Similarly, the Supreme Court of Illinois reasoned that to ensure the public trust doctrine's validity, members of the public must be granted standing, noting " $[t] o$ tell them that they must wait upon governmental action is often an effectual denial of the right for all time." Paepcke v. Pub. Bldg. Comm'n of Chicago, 263 N.E.2d 11, 18 (Ill. 1970); see also Nat'l Audubon Soc'y v. Superior Court of Alpine Cnty., 658 P.2d 709, 716 n.11 (Cal. 1983) (concluding plaintiffs have standing to sue for violations of public trust); Cir. for Biological Diversity, 83 Cal. Rptr. 3d at 600 (explaining there is no reason in principle why members of public should be denied standing to maintain appropriate action in enforcing public trust in wildlife).

42. Joseph L. Sax, The Public Trust Doctrine in Natural Resources Law: Effective Judicial Intervention, 68 MicH. L. REv. 471, 490 (1970) (explaining courts' skepticism toward agency actions).

43. Mary Christina Wood, Advancing the Sovereign Trust of Government to Safeguard the Environment for Present and Future Generations (Part II): Instilling a Fiduciary Obligation in Governance, 39 ENVTL. L. 91, 112 (2009) (explaining major difference between agency's statutory duty and trust duty is courts give greater deference to agency's decision in statutory context). In a trust context, however, courts scrutinize the agency's decision to determine if the agency acted appropriately as trustee. $I d$. 


\section{B. The Public Trust in Wildlife}

The public trust doctrine has long recognized wildlife as a protected resource, an interest that has expanded as public needs and perceptions shifted. ${ }^{44}$ Recently, the California Court of Appeals recognized wildlife as a "natural resource[] of inestimable value to the community as a whole." 45 With the expansion of the public's interest in wildlife, the public trust doctrine can be used to protect wildlife resources from the state legislatures, agencies, and administrative personnel who fail to perform their duties in protecting the public's interest in preserving wildlife. ${ }^{46}$ Specifically, states have the duty to regulate and conserve wildlife, in their sovereign capacity, as trustees of wildlife for the benefit of the people. ${ }^{47}$

In Greer v. Connecticut (Greer), ${ }^{48}$ the Supreme Court held the citizens in their "collective sovereign capacity" owned the wildlife within a state's borders, and the state has the responsibility to control the wildlife "as a trust for the benefit of the people." 49 In essence, the Court adopted the public trust doctrine by placing a duty on the state to protect the public's interest in wildlife under the sovereign ownership theory. ${ }^{50}$ Even though Hughes $v$. Oklahoma

44. Musiker, supra note 20, at 92 (explaining shift in perceptions toward public trust doctrine); see, e.g., Marks v. Whitney, 491 P.2d 374, 380 (Cal. 1971) (clarifying traditional public trust rights were related to navigation, commerce, and fishing before court extended rights to tidelands); Nat'l Audubon Soc'y, 658 P.2d at 719 (recognizing evolution of public trust based on shifts in public values, which are now focused on preserving tidelands in their natural state as public use); see also Ctr. for Biological Diversity, 83 Cal. Rptr. 3d at 597 (explaining elements of public trust doctrine); Meyers, supra note 37, at 729 (citing M. BEAN, ThE Evolution of NATIONAL WiLdLIFE LAW 12 (1983)) (noting ownership of wildlife, like water, historically has been treated as aspect of sovereignty); Musiker, supra note 20, at 91 (noting even though Illinois Central reviewed public trust in light of waterways, "the core of the public trust doctrine applies more generally to wildlife").

45. Ctr. for Biological Diversity, 83 Cal. Rptr. 3d at 599 (recognizing public trust doctrine encompasses protection of undomesticated birds and wildlife).

46. Musiker, supra note 20 , at 109 (explaining public trust doctrine can protect wildlife resources from state legislatures, agencies, and administrative personnel who fail to perform duties).

47. $I d$. at 88, 91-92 ("Like their ownership of the beds beneath navigable waterways, states own wildlife in their sovereign capacity and thereby have a public trust duty to prevent impairment of this common resource"). (1979).

48. 161 U.S. 519 (1896), overruled by Hughes v. Oklahoma, 441 U.S. 322

49. Id. at 529 (holding wildlife within state's borders was owned by citizens in their "collective sovereign capacity" to be exercised by state as trust for public benefit).

50. Musiker, supra note 20, at 93 (adopting public trust doctrine by placing duty on state to protect public's interest in wildlife under sovereign ownership theory). 
(Hughes) ${ }^{51}$ overruled Greer on the constitutionality of interstate wildlife shipping, Hughes made "ample allowance for preserving. . . the legitimate state concerns for conservation and protection of wild animals underlying the 19th-century legal fiction of state ownership." 52

This concept of the public trust in wildlife was further developed when the Commonwealth of Virginia sued the ship owner responsible for an oil spill in the Chesapeake Bay which killed approximately 30,000 migratory birds in In re Steuart Transportation Co.. ${ }^{53}$ The United States District Court for the Eastern District of Virginia found that even though Virginia did not own the birds in question, the State was still able to bring a claim against the ship owner under the public trust doctrine. ${ }^{54}$ The court stated that under the public trust doctrine, Virginia and the United States had "the right and the duty to protect and preserve the public's interest in natural wildlife resources. Such right does not derive from ownership of the resources but from a duty owing to the people." ${ }^{55}$ Essentially, Virginia acted on behalf of its citizens as the trustee of the public trust. ${ }^{56}$

The California Court of Appeals arrived at a similar conclusion in Center for Biological Diversity, Inc. v. FPL Group, Inc. ${ }^{57}$ when a wildlife protection group sued the owners and operators of wind turbine electric generators for the destruction of thousands of birds in violation of the public trust doctrine. ${ }^{58}$ The fatalities included "between 17,000 and 26,000 raptors-more than a thousand Golden Eagles, thousands of hawks, and thousands of other raptors." ${ }^{9} 9$ The California court resolved private parties have the right to insist state agencies protect and preserve birds and other wildlife in their state

51. 441 U.S. 322 (1979).

52. Hughes, 441 U.S. at 335-36 (explaining case made ample allowance for preserving legitimate state concerns for conservation and protection of wild animals). To find a state interest in protecting wildlife, states have used theories such as state ownership and their public trust duties, the public trust itself, or they simply adopt the concept of the public trust through a state's role as a trustee over wildlife. See Musiker, supra note 20, at 94.

53. In re Steuart Transp. Co., 495 F. Supp. 38, 39 (E.D. Va. 1980) (finding even though Virginia did not own birds in question, it was able to bring claim against ship owner).

54. Id. at 39-40 (explaining reasoning behind Virginia's action).

55. Id. at 40 (explaining why public trust doctrine applies).

56. Id. (explaining Virginia's duty to protect public's interests).

57. 83 Cal. Rptr. $3 d 588$ (Cal. Ct. App. 2008).

58. Id. at 592 (illustrating application of public trust regarding wildlife).

59. Id. (explaining devastation caused by turbine electric generators). 
because they are public trust resources. ${ }^{60}$ Moreover, as members of the public, the court recognized private parties are entitled to bring a public trust action to enforce the trust when an agency fails to perform its duties under the trust. ${ }^{61}$

\section{Water Quality as an Essential Component of the Public Trust}

Since its origin, the public trust doctrine has included the public's interest in navigable waterways. ${ }^{62}$ Recent cases have further expanded this coverage to include non-navigable waterways as well as tidelands and water bodies for their ecological significance in their natural states. ${ }^{63}$ Additionally, courts have long recognized the public trust doctrine as a tool to protect the public's interests in "fish, wildlife, recreational, and environmental values"-uses that are greatly impacted by the quality of the water. ${ }^{64}$ In effect, by protecting these various uses of the water, water quality has become an essential component of many public trust uses. ${ }^{65}$ Such uses have even expanded to encompass the preservation of public trust lands for nontraditional recreational and ecological purposes, such as scientific study, scenic values, to maintain air purity, and to protect wildlife nesting and feeding sites. ${ }^{66}$

60. Id. at 603 (asserting individual right to compel agency action).

61. Id. at 601 (describing details of private right of action).

62. Ill. Cent. R.R. v. Illinois, 146 U.S. 387, 452 (1892) (noting lands under navigable waters are held in trust for people of state for navigation, commerce, and fishing).

63. See, e.g., Marks v. Whitney, 491 P.2d 374, 380 (Cal. 1971) (noting preservation of tidelands is important in protecting public's interest in ecological preservation); Nat'l Audubon Soc'y v. Superior Court of Alpine Cnty., 658 P.2d 709, 711, 715,720 (Cal. 1983) (recognizing scenic and ecological value of Mono Lake to be in public interest, application of doctrine to non-navigable source streams, and importance of water quality to system).

64. Johnson, supra note 6, at 498 (explaining how public trust encompasses water quality); see Kootenai Envtl. Alliance v. Panhandle Yacht Club, Inc., 671 P.2d 1085, 1095 (Idaho 1983) (holding state agencies could consider effect of encroachments in water on "navigation, fish and wildlife habitat, aquatic life, recreation, aesthetic beauty and water quality," in relation to public trust doctrine); United States v. State Water Res. Control Bd., 227 Cal. Rptr. 161, 150-52 (Cal. Ct. App. 1986) (finding board was within its powers when it evaluated appropriation permits by considering impact of water quality in protecting public's interest in fish and wildlife resources).

65. Johnson, supra note 6 , at 498 (noting essential nature of water quality element).

66. Marks, 491 P.2d at 380 (explaining flexibility in notion of public uses to incorporate public's changing needs); Nat'l Audubon Soc'y, 658 P.2d at 719 (describing expanding definition of water quality dependent uses). 
In one of the earliest water pollution cases, People v. Gold Run Ditch $\mathcal{E}^{2}$ Mining Co., ${ }^{67}$ the Supreme Court of California recognized that polluting public waters was "an unauthorized invasion of the rights of the public to its navigation." 68 The case arose when Gold Run Ditch and Mining Company discharged large amounts of rock and sand from its mining operations into the river and bay, effectively filling the waters to the extent it hindered navigation. ${ }^{69}$ As a result, the court held the discharge was an encroachment on the public's interest in navigable waters and the soil under the water, which the state held as trustee for the benefit of the public in the public trust. ${ }^{70}$

In 1971, the Supreme Court of California further recognized the public trust doctrine covered the preservation of tidelands in their natural state in Marks $v$. Whitney (Marks). ${ }^{71}$ The court stated there is a public recognition of the importance of the "preservation of [tidelands]. . . in their natural state, so that they may serve as ecological units for scientific study, as open space, and as environments which provide food and habitat for birds and marine life, and which favorably affect the scenery and climate of the area."72 This tremendous expansion of public trust uses placed a great emphasis on preserving the water quality on which these uses rely. ${ }^{73}$

Twelve years later, in the en banc decision of National Audubon Society $v$. Superior Court, ${ }^{74}$ the Supreme Court of California not only held the public trust doctrine extended to non-navigable tributaries, but the court focused on the detrimental impact of low water quality on public trust uses. ${ }^{75}$ The Department of Power of the City of Los Angeles was granted a permit to divert water from four of the five non-navigable streams feeding Mono Lake; this diversion began

67. People v. Gold Run Ditch \& Mining Co., 4 P. 1152 (Cal. 1884) (finding discharge violated public trust doctrine).

68. Id. at 1155 (describing specific circumstances that led to finding infringement of public rights).

69. Id. at 144-45 (describing background to litigation).

70. Id. at 151-52 (holding that by allowing debris from hydraulic mining operation to discharge into stream, mining operation was infringing on public and private rights despite longstanding custom).

71. Marks, 491 P.2d at 380 (holding legislation, patent, and public trust doctrine, covered tidelands at issue).

72. Id. (describing various uses of public trust waterways and myriad reasoning for holding such).

73. Johnson, supra note 6, at 496 (describing that while Marks did not specifically include water quality as public interest, it was included in public uses).

74. 658 P.2d 709 (Cal. 1983).

75. Id. at 719,721 (describing purpose and scope of public trust doctrine). 
to significantly disrupt the ecological balance of the lake. ${ }^{76}$ Observing there was "little doubt that both the scenic beauty and the ecological values of Mono Lake [were] imperiled" by the City's permit, the court found that approving the diversion without considering the public trust values would lead to the "needless destruction of those values." 77 By increasing the salinity of the lake, the diversions threatened to imperil the ecological value of the lake and destroy the food sources and nesting sites for millions of local and migratory birds. ${ }^{78}$ The court also noted the decrease in the water level of Mono Lake exposed gull rookeries to predators, forcing California gulls to abandon their nesting sites. ${ }^{79}$ In effect, this decision revolved around an issue of water quality that caused substantial damage to the surrounding environment, and effectively injured the public's interest in using the lake for recreation, scenic beauty, and its ecological value. ${ }^{80}$

\section{Current Water Quality and Wildlife Issues Arising From the Agricultural. Pollutant Atrazine}

\section{A. Agricultural Pollution and its Effects on Water Quality}

In recent decades, agricultural pollution has been recognized for its tremendous detrimental impact on the water quality of our nation's waters. ${ }^{81}$ There are more than 330 million acres of land in the United States used for agriculture. ${ }^{82}$ Agricultural pollutants such as pesticides, nutrients, sediment, and soluble salts commonly end up in streams, rivers, and lakes due to leaching and runoff from agricultural fields. ${ }^{83}$ The U.S. Department of Agriculture determined seventy-five percent of all pesticides used in the United

76. $I d$. at 711 (describing background to dispute). case).

77. Id. at 711-12 (supporting contention that public trust be considered in

78. Id. at 715 (describing background and history of litigation).

79. Nat'l Audubon Soc'y, 658 P.2d at 716 (noting severe enviornmental impact issues presented by case). levels)

80. Id. (describing in particular, grave toll taken on California gull and water

81. Robert W. Adler, Water Quality and Agriculture: Assessing Alternative Futures, 25 Environs EnvtL. L. \& Pol'y J. 77, $77-78$ (2002) (discussing history of modern water pollution with regards to agricultural pollution).

82. Agriculture, U.S. Envtl. Prot. AgenCy, http://www.epa.gov/owow_keep/ NPS/agriculture.html (last updated Feb. 10, 2010) (providing background for fact sheets and reports).

83. John D. Sutton, U.S. Dep't of Agric., WAter Quality and Agriculture STATUS, Conditions, AND TrEnds 7 (July 1997), available at http://www.nrcs.usda. gov/Internet/FSE_DOCUMENTS/nrcs143_012448.pdf (describing background to detailed report). 
States are for agricultural purposes, seventy percent of which are herbicides. ${ }^{84}$ Sometimes these pesticides turn up in surface and ground water at rates exceeding United States health standards..$^{85}$ Current farming practices amplify these problems by encouraging farmers to use excessive amounts of agricultural chemicals and farm in "environmentally-sensitive areas" in an effort to increase the output of each farm. ${ }^{86}$

\section{B. Agricultural Pollution and its Effects on Wildlife}

Agricultural pollution affects not only the quality of the nation's water, but also the wildlife that depend on the water, which makes agriculture a "leading cause of species endangerment and extinction."87 Between 1992 and 2001, a United States Geological Survey found pesticide concentrations exceeded the water-quality benchmarks necessary to sustain "aquatic life and . . . fish-eating wildlife in more than half of the streams with substantial agricultural and urban areas in their watersheds." 88 Furthermore, "[a]gricultural streams had concentrations that exceeded one or more benchmarks at 57 percent of sites" that frequently contained several herbicides, including atrazine. ${ }^{89}$ To top this off, agricultural pollutants have adversely affected the water quality in the United States to the point that many species of wildlife are suffering potentially fatal ailments. ${ }^{90}$ Studies have discovered pesticides can cause decreased hormonal levels in fish, developmental and reproductive anomalies or death in amphibians, and fatalities in waterfowl. ${ }^{91}$

84. Id. at 5 (describing conclusions and findings of report).

85. Id. at 8 (showing strong need for concerted action in this area).

86. Adler, supra note 81 , at 90 (discussing increase of chemicals for agricultural purposes).

87. Robert W. Adler et al., The Glean Water Act 20 Years Later 177 (Island Press, 1993) (discussing extent of endangerment and extinction).

88. Robert J. Gilliom \& Pixie A. Hamilton, U.S. Dept. of the Interior: U.S. Geological Survey, Pesticides in the Nation's Streams and Ground Water, 1992-2001 - A SUMmary 2 (Mar. 2006), available at http://pubs.usgs.gov/fs/2006/ 3028/pdf/fs2006-3028.pdf ("Of the 178 streams sampled nationwide that have watersheds dominated by agricultural, urban, or mixed land uses, 56 percent had one or more pesticides in [the] water that exceeded at least one aquatic-life benchmark.").

89. Id. at 2 (discussing potential effects of pesticides on aquatic life and wildlife).

90. ADLER, supra note 87, at 177 (stating "approximately thirty-seven percent of the 436 species listed in the Endangered Species Information Database are endangered in part due to effects of irrigation and the use of pesticides").

91. Lal, supra note 3 , at 455 (detailing that pesticides affect or damage gonadal development, fertilization, fecundity, and lower hormonal levels in Indian fishes); Manosa, supra note 3, at 191 (finding herbicides cause loss in biodiversity and greatly damage diving ducks and coot populations); Rouse, supra note 3, at 


\section{The Effects of the Herbicide Atrazine on Wildlife}

A diverse range of wildlife species suffer devastating, if not fatal, responses to herbicides and pesticides in their water sources. ${ }^{92}$ A prime example of this is the unprecedented rates of demasculinization in populations of amphibious wildlife linked to the herbicide atrazine. ${ }^{93}$ Atrazine is one of the most extensively used pesticides both in the United States and throughout the world..$^{94}$ From 1993 to 1997, California used between 38,000 to 60,000 pounds of atrazine each year, and it has been detected in numerous surface waters within the state. ${ }^{95}$ This powerful herbicide, produced by Syngenta, is extremely effective in controlling weeds in corn, sorghum, and sugarcane crops. ${ }^{96}$ Many in the scientific community, however, believe atrazine causes reproductive and developmental defects in wildlife and increases incidences of cancer in humans exposed to the herbicide. ${ }^{97}$ In 2003, the European Union banned atrazine because it believed a ban on the herbicide was the only way to prevent "ubiquitous and unpreventable water contamination." 98 Yet, even in the wake of studies indicating hormonal impairment in wildlife and humans, the United States Environmental Protection Agency (EPA) has refused to recognize the potential detrimental effects of atrazine. ${ }^{99}$

799 (explaining finding that nitrogen concentrations near Great Lakes are enough to cause death and developmental abnormalities in amphibians in addition to adversely affecting other animals in aquatic ecosystems).

92. For further discussion, see supra note 91 and accompanying text.

93. Hayes, supra note 1, at 4576 (discussing high rates of demasculinization in amphibians).

94. Pesticide Atrazine Can Turn Male Frogs into Females, ScienceDaily (Mar. 1, 2010), http://www.sciencedaily.com/releases/2010/03/100301151927.htm (noting extensive use of atrazine around world); see also Atrazine Updates, U.S. ENVTL. Prot. AGENCY, http://www.epa.gov/pesticides/reregistration/atrazine/atrazine update.htm (last updated Nov. 17, 2011) (noting extensive use of atrazine in United States).

95. Derek W. Gammon et al., Med. Toxicology Branch Cal. Dep't of Pesticide Regulation, Cal. Envtl. Prot. Agency, Atrazine Risk Characterization DoCUMENT 7, 15 (Aug. 15, 2001), available at http://www.cdpr.ca.gov/docs/risk/ rcd/atrazine.pdf (detailing atrazine use in California).

96. Atrazine Updates, supra note 94 (providing background on herbicide atrazine).

97. J.B. Sass \& A. Colangelo, European Union Bans Atrazine, While the United States Negotiates Continued Use, 12 Inr'L J. of Occupational \& Envtl. Health 260, 261-62 (2006) (noting scientific concerns of potential human harm).

98. Id. at 260 (discussing European Union ban on atrazine).

99. Id. (discussing existence of evidence suggesting Syngenta made efforts to influence EPA in atrazine assessment through private meetings and sponsoring studies which concluded there were no harmful effects caused by atrazine on humans or wildlife). 
In one study, scientists found that when they raised male African clawed frogs to sexual maturity, all of the male frogs not treated with atrazine retained their male reproductive organs and traits. ${ }^{100}$ Ten percent of the frogs treated with atrazine, however, displayed female sexual organs and traits. ${ }^{101}$ In addition, males exposed to atrazine had reduced testosterone levels and suffered significantly decreased fertility rates. ${ }^{102}$ Another study found American bullfrogs, northern leopard frogs, and wood frogs all exhibited deformed larvae and respiratory distress in response to increased doses of atrazine. ${ }^{103}$ Yet another study demonstrated that northern leopard frog larvae exposed to atrazine during development often suffered premature gonadal development. ${ }^{104}$ Furthermore, when atrazine was exposed to nitrate, a widely used agricultural nutrient, the scientists observed drastic changes in the northern leopard frog sex ratios. ${ }^{105}$

Entire amphibian populations face extinction due to reproductive failures, developmental mutations, and hermaphroaditism caused by the runoff of agricultural pollutants into the waters they depend on for survival. ${ }^{106}$ By disrupting the balance of the aquatic ecosystem, agricultural pollutants pose substantial threats to the stability of these fragile systems and jeopardize the survival of an inestimable number of species throughout the United States. ${ }^{107}$

\section{Clean Water Act}

The objective of the CWA is to "restore and maintain the chemical, physical and biological integrity of the Nation's wa-

100. Tyrone B. Hayes et al., Atrazine Induces Complete Feminization and Chemical Castration in Male African Clawed Frogs (Xenopus Laevis), 107 Proc. OF THE NAT'L ACAD. OF ScIs. OF THE U.S. 4612, 4613 (Mar. 2010) (discussing atrazine exposure in adult amphibians).

101. Id. at 4612 (discussing reproductive consequences of atrazine on African clawed frogs).

102. Id. at 4614 (discussing additional reproductive consequences of atrazine).

103. John W. Allran \& William H. Karasov, Effects of Atrazine on Embryos, Larvae, and Adults of Anuran Amphibians, 20 Envtl. ToXicology \& Chemistry 769, 772 (2001) (noting differences atrazine caused in subject species).

104. Orton, supra note 2, at 65 (analyzing effects of atrazine and sex ratios of Northern Leopard Frog).

105. Id. (analyzing additional effects of atrazine and sex ratios of Northern Leopard Frog).

106. For a discussion of the impact of agricultural pollutants on amphibians, see supra notes $100-105$ and accompanying text.

107. For a description of agricultural pollution's impact on fish and birds, see supra note 91 and accompanying text. 
ters."108 While the CWA has made significant strides in improving water quality through point source regulation, it has been ineffective in regulating nonpoint source pollution, the "largest remaining threat to water quality and source of water quality impairments in the nation." 109 Nonpoint and point source pollution differ in that the former is the "runoff from broad sources such as fields" whereas the latter is "emitted from discrete sources such as sewage pipes." 110 Today, thirty years after the CWA was enacted, the United States is still plagued with polluted waters that fail to meet the water quality standards. ${ }^{11}$ In 2004, after assessing the water quality in $16 \%$ of the nation's streams, states reported that $44 \%$ of these waters were impaired and failed to meet one or more of its designated uses. ${ }^{112}$ Of the 11.8 million lake acres, $30 \%$ were impaired for supporting fish, shellfish, and wildlife, as were $36 \%$ of the 446,617 miles of assessed streams. ${ }^{113}$

In 2000, the National Water Quality Inventory reported "agricultural nonpoint source . . pollution was the leading source of water quality impacts on surveyed rivers and lakes, the second largest source of impairments to wetlands, and a major contributor to contamination of surveyed estuaries and ground water."114 Even though the CWA is slowly expanding to regulate more agricultural pollution through point source pollution permitting programs, much of it remains unregulated as nonpoint source pollution. ${ }^{115}$

108. 33 U.S.C. § 1251 (a) (setting forth objectives of CWA and measures to achieve those objective).

109. Nonpoint Source Program and Grants Guidelines for States and Territories, 68 FED. REG. 60656 (Oct. 7, 2003) (noting continued threat of nonpoint source pollution in United States); see Johnson, supra note 6, at 486 (recognizing nonpoint pollution as being "primarily responsible for the failure in most states to meet the Clean Water Act's water quality standards"); see also Zaring, supra note 7, at 515 (discussing ineffectiveness of CWA in addressing nonpoint source pollution).

110. Zaring, supra note 7 , at 515 (explaining differences in pollution discharges).

111. See Johnson, supra note 6, at 486 (describing failure of most states to meet CWA water quality standards).

112. U.S. Envtl. Prot. Agency, National Water Quality Inventory: RePORT to Concress, 2004 Reporting Cycle: Findings 9 (2009), http://water.epa. gov/lawsregs/guidance/cwa/305b/upload/2009_05_20_305b_2004report_report 2004pt3.pdf (reporting results of national water quality assessment).

113. National WATER QUALity INVENTORY, supra note 112, at 10, 14 (noting impairment of nation's lakes for designated use).

114. Agriculture, supra note 82 (discussing study on agricultural nonpoint source pollutants in rivers, lakes, wetlands, estuaries, and ground water).

115. Both Concentrated Animal Feeding Operations (CAFOs) and certain agricultural equipment are considered point sources and require NPDES permits under the CWA. See 40 C.F.R. \$ 122.23(a) (2006) (requiring CAFOs to have NPDES permits); Concerned Area Residents for the Env't v. Southview Farm, 34 F.3d 114, 119 (2d Cir. 1994) (recognizing manure spreading vehicles as point 
Nonpoint source pollutants from runoff typically include: "[e]xcess fertilizers, herbicides and insecticides from agricultural lands ... [s] ediment from improperly managed construction sites, crop and forest lands and eroding streambanks, [s]alt from irrigation practices, [and] [b] acteria and nutrients from livestock."116

In 1972, Congress attempted to address the agricultural problem by implementing $\S 208$ of the CWA, which "directed states to adopt area-wide waste treatment management plans." 117 However, under $\S 208$, the governor of each state was responsible for designating areas with water quality control problems, the boundaries of that area, and a representative organization to develop an effective area-wide waste treatment management plan.118 These plans were to include "agriculturally and silviculturally related nonpoint sources of pollution . . . and their cumulative effects, runoff from manure disposal areas, and . . . land used for livestock and crop production," as well as "set forth procedures and methods (including land use requirements) to control to the extent feasible such sources." 119 After a great deal of time and money was spent in developing the $\S 208$ plans, few mandatory requirements were adopted, which effectively made the plans voluntary. ${ }^{120}$ Nearly two hundred $\S 208$ plans were created, of which almost all were abandoned in the 1980s due to a lack of federal funding, inadequate water quality data, poor EPA management, and a lack of public ed-

sources); see also Enforceable State Mechanisms for the Control of Nonpoint Source Water Pollution, EnvTl. LAw InST., ELI Proj. No. 970300, 4 (1997) [hereinafter Enforceable State Mechanisms], available at http://www.epa.gov/owow/NPS/elistudy/nonpoint. pdf (examining state law enforcement mechanisms controlling nonpoint source pollution). Nonpoint source pollution is not defined in the CWA, however, it is often recognized as pollution which does not fall under the definition of a point source in $\S 1362(14)$ of the CWA and it is often described as pollution coming from a "diffuse source" associated with precipitation, rather than a point source, which is then carried by runoff into lakes, rivers, wetlands, coastal areas, and groundwaters. What is Nonpoint Source Pollution?, ENvTl. Prot. Agency, http:// water.epa.gov/polwaste/nps/whatis.cfm (last updated Sept. 29, 2011).

116. What is Nonpoint Sousce Pollution?, supra note 115 (providing examples of common nonpoint source pollutants).

117. Adler, supra note 81 , at 78 (recalling 1972 Congressional attempt at addressing pollutant problems).

118. 33 U.S.C. $\$ 1288(\mathrm{a})(1)$-(2) (1972) (providing guidelines on how to identify and address water quality control problems).

119. 33 U.S.C. $\$ 1288$ (b) (2) (F) (i)-(ii) (providing guidelines on what needs to be included in waste treatment management plans).

120. Adler, supra note 81 , at 79 (noting $\$ 208$ did not include many mandatory provisions); see Zaring, supra note 7, at 522 (describing practical effect of $\$ 208$ ). 
ucation and awareness. ${ }^{121}$ States were also "unwilling to provoke powerful agricultural constituencies" by creating strict regulations when the government had not required them to do so. ${ }^{122}$

Dissatisfied with the state of nonpoint pollution regulation, Congress amended the CWA by adding $\S 319$ to strengthen agricultural and runoff controls in 1987. ${ }^{123}$ This new nonpoint pollution control provision stated "it is the national policy that programs for the control of nonpoint sources of pollution be developed and implemented in an expeditious manner so as to enable the goals of [the CWA] to be met through the control of both point and nonpoint sources of pollution." 124 In many respects $\S 319$ is very similar to $\S 208$, as it too failed to significantly encourage the states to develop more stringent assessments and plans. ${ }^{125}$ Section 319 required "states to complete comprehensive nonpoint source pollution assessments statewide, but where possible on a watershed basis; and to prepare and implement comprehensive nonpoint source pollution control plans to address the identified problems." ${ }^{126}$ By way of $\S 319$, Congress increased the substantive standard for runoff controls only slightly-raising the standard from "to the extent feasible" in $\S 208$ to "the maximum extent practicable" in $\S 319 .{ }^{127}$

In 1996, the EPA and the states agreed to address nine key elements in an effort to upgrade the state nonpoint source management plans. ${ }^{128}$ These elements consisted of the following: creating long- and short-term goals for restoring water quality, strengthening working partnerships, balancing approaches for state and watershed management, focusing on eliminating current water quality impairment problems and preventing future ones, upgrading and implementing all program requirements to be more flexible with targeted approaches to control, and creating feedback loops for

121. Adler, supra note 81 , at 184 (listing reasons behind abandonment of $\S 208$ plans).

122. Zaring, supra note 7, at 524 (explaining state's rationale for not enacting strict agricultural regulations).

123. Id. at 525 (asserting Congressional dissatisfaction with state if nonpoint source regulation led to 1987 amendment of CWA).

124. 33 U.S.C. $\$ 1251(\mathrm{a})(7)$ (1987) (addressing need to implement new programs to address nonpoint source pollution).

125. Adler, supra note 81 , at 80 (analyzing effect of $\S 319$ ).

126. Id. (footnote omitted) (elaborating upon requirements of $\S 319$ ).

127. Id. (comparing and quoting $\S 319$ runoff control standard to $\S 208$ ).

128. Nonpoint Source Program and Grants Guidelines for States and Territories, supra note 109, at 60654 (describing further efforts to improve nonpoint source management plans). 
evaluation and revisions of the programs. ${ }^{129}$ These efforts, however, still inadequately incentivized the states to create more stringent pollution control programs. ${ }^{130}$

To add to these problems, there continued to be insufficient funding, a lack of consequences for failure to comply with $\$ 319$, and political pressure on state agencies to restrain from developing nonpoint source pollution plans. ${ }^{131}$ Section 319 provides that if a state failed or chose not to submit a nonpoint source monitoring report, the responsibility simply shifted to the EPA without any consequences to the state. ${ }^{132}$ In addition, farmers had very little incentive to voluntarily participate in the plans; because they did not bear the "total costs of off-farm pollution and erosion" there was no reason for them to change their practices. ${ }^{133}$ Finally, the states continued to find themselves faced with significant political and monetary pressure from powerful agricultural interests if they choose to voluntarily regulate nonpoint source pollution. ${ }^{134}$

Section 303 of the CWA offers an additional means to address nonpoint source pollution by requiring states set water quality standards for water bodies within the state and determine which of those waters are impaired. ${ }^{135}$ Impaired water bodies are then placed on the $\S 303(\mathrm{~d})$ list for which the state must create a Total Maximum Daily Load (TMDL). ${ }^{136}$ A TMDL is the "calculation[] of

129. The Virgin Islands Non Point Source Pollution Mgmt. Plan: Non Point Source: 9 Key Elements of an Effective Territorial Program, U.S. V.I. Dept. OF Planning \& Natu. RAL RES. (Jan. 10, 2000), http://www.dpnr.gov.vi/dep/FactSheets/nonpointelements.htm (listing key elements).

130. Zaring, supra note 7, at 527 (finding 1996 efforts insufficient incentive to guarantee state action).

131. Id. (describing additional problems with implementing more stringent pollution control programs).

132. Id. (explaining failure of $\$ 319$ to reduce nonpoint source pollution).

133. Id. at 528 (explaining failure of $\$ 319$ to reduce nonpoint source pollution).

134. See Barbara A. Bardes et al., American Government and Politics ToDAY: The Essentials 2010-2011, 226 (Carolyn Merrill et al. eds., 2012-2012 ed. 2010) (explaining effect of agricultural interest groups on legislation). Even though they "represent less than 1 percent of the U.S. population," farmers have had a great deal of influence on legislation because they are "geographically dispersed and therefore have many representatives and senators to speak for them." Id. See also Zaring, supra note 7, at 523-24 (noting voluntary nature of $\S 208$ ). Zaring described the unbalanced competition between agricultural polluters and other water users, noting agricultural interests "have a stronger incentive per person" to lobby for their interests than those who would only receive a small benefit from nonpoint source regulation. Id. at 542.

135. 33 U.S.C. $\$ 1313$ (2006) (establishing water quality standards).

136. See Reed D. Benson, Pollution Without Solution: Flozv Impairment Problems Under Clean Water Act Section 303, 24 STAN. ENVTL. L.J. 199, 218-19 (2005) (explaining states' obligations under $\$ 303$ ). 
the maximum 'load' of a pollutant that a waterbody can receive from all sources, including point, nonpoint, and background sources, without exceeding the water quality standards for the pollutant." 137 Section 303 requires a state include water bodies that are impaired solely due to nonpoint source pollution from agricultural runoff. ${ }^{138}$

Because no authority exists to regulate these nonpoint source polluters, however, the responsibility to develop TMDLs once again falls into the hands of the state and local agencies subject to the pressures of "politically powerful interests" concerned with TMDL program costs. ${ }^{139}$ In effect, $\S 303$ faces essentially the same problems as $\$ \S 208$ and 319 in that it leaves regulation up to the state to enforce, while simultaneously failing to set limits on nonpoint source pollution. ${ }^{140}$

While many states have attempted to fill the gaps left by the CWA's lack of sufficient legislation regulating nonpoint source pollution, most are unable to do so through the patchwork of laws they have passed. ${ }^{141}$ The difficulty with these mechanisms is they vary greatly by state, watershed, and activity, and therefore provide no regional standard. ${ }^{142}$ Additionally, the responsibilities of setting and implementing the standards and enforcing the state laws are often delegated to various groups that have no communication method to ensure they can effectively address any problems that may arise. ${ }^{143}$ Therefore, it is necessary to find other avenues for the public to ensure their interests in wildlife and water quality depen-

137. Meline MacCurdy, Private Landowners Granted Right to Challenge EPA's Clean Water Act "Impaired Waters" Listing Decisions, MARTEN LAw (Mar. 3, 2011), http://www.martenlaw.com/newsletter/201 10303-impaired-waters-listing-decisions (defining "total maximum daily load" for purposes of $\$ 303(d)$ ).

138. Pronsolino v. Nastri, 291 F.3d 1123, 1140-41 (9th Cir. 2002) (finding $\$ 303(d)$ (1) listing and TMDL requirements include waters "impaired only by nonpoint sources of pollution").

139. Benson, supra note 136, at 227 (analyzing source of controversy over TMDL program).

140. See Endre Szalay, Comment, Breathing Life into the Dead Zone: Can the Federal Common Law of Nuisance Be Used to Control Nonpoint Source Water Pollution?, 85 TuL. L. Rev. 215, 239 (2010) (criticizing voluntary nature of $\$ 319$ ).

141. These legal mechanisms may include general discharge provisions, erosion control, enforcement authorities, land use regulations, adopting accepted agricultural practice requirements, nutrient management plans, using BMPs as enforcement mechanisms, and pesticide handling provisions. Enforceable State Mechanisms, supra note 115, at 37-49.

142. Id. at 54 (comparing states' primary responses to nonpoint source pollution).

143. See id. at i (comparing states' primary responses to nonpoint source pollution). 
dent public trust uses are protected from agricultural nonpoint source pollution.

\section{The Public Trust Doctrine as an Alternative Means of Addressing Nonpoint Source Pollution}

The shortcomings of $\S 319$ have left the American public to suffer the consequences of a nearly unregulated agricultural nonpoint source water pollution predicament. ${ }^{144}$ Not only are the effects of the pesticides, herbicides, fertilizers, and sediment taking a toll on the quality of our nation's waters, they are also detrimental to aquatic environments, biodiversity, and the wildlife which depend solely on these waters. ${ }^{145}$

The topic of nonpoint source pollution regulation is politically charged, often revolving around the potential costs incurred by the polluters if more stringent standards are appropriately enforced. ${ }^{146}$ In addition, the strength of the agricultural lobbying sector allows it to place considerable pressure on legislators to prevent legislation running counter to the interests of its constituents. ${ }^{147}$ With threats of financial repercussions and political turmoil, states are often forced to create toothless pollution control plans or, worse yet, none at all. ${ }^{148}$ Fortunately, the judicial system, free from the confines of the special interest groups' excessive political pressure, is in a prime position to protect the public's interests through the enforcement of pollution control plans. ${ }^{149}$ It is in this context the public should use the public trust doctrine in wildlife, along with the related public trust uses adversely affected by poor water quality, as a tool to pressure their state legislatures and agencies to uphold their duties to protect such interests when developing, implementing, and reevaluating $\S 319$ agricultural nonpoint source pollution control plans.

144. Zaring, supra note 7 , at 517 (discussing extent of nonpoint source pollution in surface and ground waters, significantly affecting water quality).

145. See discussion supra Part III.B-C.

146. See Marc O. Ribaudo et Al., U.S. Dep't of Agric., AER-782, Economics of Water Quality Protection From Nonpoint Sources: Theory and Practice 1 (1999), available at http://www.ers.usda.gov/publications/aer782/aer782.pdf (explaining negative consequences of stronger enforcement).

147. Zaring, supra note 7 , at 515 (noting strength of agricultural interest groups' influence on legislation); Bardes, supra note 134, at 226 (explaining effect of agricultural interest groups on legislation).

148. See Zaring, supra note 7, at 523-24 (explaining weaknesses of $\S 208$ ).

149. See Wood, supra note 30 , at 75-77 (finding "judicial branch remains the ultimate guardian of the [public] trust"). 
Villanova Environmental Law Journal [Vol. XXIII: p. 1

In California, state agencies must consider the public trust when planning and allocating water resources in an effort to minimize harm to public interests. ${ }^{150}$ Using this as a foundation, a litigant in California has several possible litigation strategies available in which they can use the public trust doctrine as a means to control agricultural nonpoint source pollution. ${ }^{151}$ For example, in an effort to save a local population of American bullfrogs suffering from reproductive and developmental defects and living in a river containing high levels of atrazine, a member of the public could bring a claim before the court under several potential causes of action. ${ }^{152}$ Assuming there is a $\S 319$ nonpoint source pollution control plan developed by the Regional Water Quality Control Board (RWQCB), the citizen could bring a claim against: (1) the RWQCB for failing to consider the public's interest in protecting the American bullfrog population, which is dependent on this river, when developing and implementing the regional water quality control plan; (2) the RWQCB for failing to comply with state and federal regulations regarding nonpoint source pollution; or (3) the permitting agency that granted a land use permit causing an increase in the level of atrazine in the river through nonpoint agricultural runoff. ${ }^{153}$ In both the second and third claims, a citizen would raise the public trust doctrine issue later in the proceeding as a means of strengthening their argument. Any of these causes of action, however, would essentially pressure an agency to enforce an agricultural nonpoint source control plan. While these are just a few of the options available to California citizens, the list is not exclusive. ${ }^{154}$ As noted earlier, California has developed a common law system best suited to apply the public trust doctrine in the manner proposed. ${ }^{155}$ Yet this does not prevent members of the public from

150. Nat'l Audubon Soc'y v. Superior Court of Alpine Cnty., 658 P.2d 709, 712, 728 (Cal. 1983) (holding state has affirmative duty to consider public trust).

151. See infra text accompanying note 153.

152. See infra text accompanying note 153.

153. See generally J.M. Gerstein et al., Univ. of Cal. Div. of Agric. \& Natural Res., State and Federal Approach to Control of Nonpoint Sources of Pollution 3-4 (2006), available at http://ucanr.org/freepubs/docs/8203.pdf (providing background information on California's Regional Water Quality Control Board (RWQCB), agency used as example in hypothetical).

154. See Ctr. for Biological Diversity, Inc. v. FPL Grp., Inc., 83 Cal. Rptr. 3d 588, 600 (Cal. Ct. App. 2008) (holding private citizens have standing to bring claim of harm to public trust).

155. See supra note 12 and accompanying text. 
attempting to enforce nonpoint source pollution control plans in their states if the common law system allows for it. ${ }^{156}$

When using the public trust doctrine to attack an agency's lack of nonpoint source pollution management, citizens might face a potential hindrance if the state agency only recognizes the public's interest in wildlife resources to the minimum extent necessary when reviewing or developing a nonpoint source pollution control plan. As noted previously, however, a reviewing court would likely regard the agency's decision with great skepticism and review it with meaningful judicial scrutiny to ensure the agency acted reasonably as trustee of the public trust. ${ }^{157}$ In this situation, if the agency failed to reasonably consider the public interest in their decision, the court could simply ask the agency to reevaluate the plan.

When recognizing a public interest in wildlife and related water quality dependent uses, an agency must address numerous issues that may not lie solely within their control. Therefore, to ensure the public interests are properly considered, several different agencies might need partner and work together to minimize agricultural nonpoint source pollution. The agencies involved could include those managing wildlife resources, monitoring agricultural nonpoint source pollution, and those who focus specifically on water quality issues, all of which would need to join forces to efficiently address agricultural nonpoint source pollution. In such a situation, there is tremendous potential for the individual agencies to form partnerships and collaborate with other agencies in an effort to protect these public trust interests. Collaboration between agencies will better protect the public interests and promote longterm relationships between the agencies, thus allowing them to more effectively respond to a diverse range of environmental concerns by approaching the ecosystem as a whole rather than in fragmented sections.

156. Numerous courts have set a foundation for wildlife protection and water quality through public trust uses even if not to the extent of California's common law. See generally Ill. Cent. R.R. v. Illinois, 146 U.S. 387, 387, 455 (1892) (noting navigable waters and soils underneath them are held in public trust); In re Steuart Transp. Co., 495 F. Supp. 38, 40 (E.D. Va. 1980) (noting State of Virginia has public trust interest in protecting wildlife for people); Kootenai Envtl. Alliance v. Panhandle Yacht Club, Inc., 671 P.2d 1085, 1094-95 (Idaho 1983) (permitting public trust cause of action); Owsichek v. Alaska Guide Licensing \& Control Bd., 763 P.2d 488, 491 (Alaska 1988) (permitting public trust claims).

157. See Sax, supra note 42 , at 490 (noting courts will review "with considerable skepticism" governmental conduct affecting public resources); see also Wood, supra note 30, at 75-77 (finding "judicial branch remains the ultimate guardian of the [public] trust"). 


\section{Conclusion}

The CWA is known as the "most comprehensive federal regulatory program for controlling discharges to surface waters." 158 It provided Americans with the rules and regulations necessary to clean up many of the nation's waters so they could meet fishing and swimming standards: a far cry from the water pollution issues that plagued the country in the $1960 \mathrm{~s}$, such as the burning of the Cuyahoga River. ${ }^{159}$ Yet, even with these vast improvements, the CWA still fails to adequately regulate agricultural nonpoint source pollution. ${ }^{160}$

To address their concerns, the public should turn to the ancient public trust doctrine-a proven and powerful enforcement mechanism available to the public with the potential to protect the nation's wildlife and waters from agricultural nonpoint source pollution. The public trust doctrine is the ideal vehicle for citizens to require state and local agencies to protect the public's interests in wildlife and water quality dependent public trust uses when developing, regulating, and reevaluating nonpoint source pollution control plans under $\$ 319$ of the CWA.

158. Robert V. Percival \& Christopher H. Schroeder, Environmental Law: Statutory and Case Supplement with Internet Guide 2009-2010, at 749 (Vicki Bean et al. eds., 2009) (providing overview of CWA).

159. See Cuyahoga Valley Water Quality, U.S. NAT'L Park Serv. Dep't of THE INTERIOR, http://www.nps.gov/cuva/naturescience/waterquality.htm (last visited Dec. 20, 2011) (providing background on pollution in Cuyahoga River).

160. See Szalay, supra note 140, at 245 (comparing weaknesses of nonpoint source pollution legislation compared to comprehensive legislation banning point source pollution). 